\title{
Entrepreneurial intentions among university students in Italy
}

\author{
Muhammad Israr * (D) and Mazhar Saleem
}

\author{
*Correspondence: misrar09@gmail. \\ com \\ University of Cassino and Southern \\ Lazio, Cassino, FR, Italy
}

\begin{abstract}
Purpose: In Italy, thousands of university graduates intend to engage in job being their first choice rather to start their own businesses. The aim of this study is to explore university students' entrepreneurial mindset and their intentions for starting a new business by investigating the deterring factors which restrict them to go towards self-employment.

Methodology: The primary data were collected by a self-prepared questionnaire to assess the role of explanatory factors such as gender, age, degree, department, previous education, previous grades, job experience, business experience, family background, entrepreneurial education, personality traits (Five Factor Model), finance and government support with the dependent variable "entrepreneurial intentions". The data was then analysed using multiple regression model.

Findings: Gender, family background, entrepreneurial education, extraversion, agreeableness, and openness to experience showed positive results while age, previous grades, and neuroticism showed a negative relationship with entrepreneurial intentions.

Limitations: This study was limited to its sample population and the set of explanatory variables which can be extended in the future research.

Originality: This study fulfils the need to identify the factors which play a significant role in influencing the students' entrepreneurial mindset. This is a latest study with the selected factors in the context of the Italian university students.
\end{abstract}

Keywords: Entrepreneurship, Entrepreneurial intentions, Entrepreneurial mindset, Entrepreneurial education

\section{Background}

Entrepreneurs are considered the backbone of the industries as they come up with innovative business ideas which ultimately contribute to the social and economic growth. In Italy, thousands of students graduate from universities every year, but only a few of them intend to start their own businesses. The preference for a paid job is one of the main reasons of unemployment rate among young (25-34) university graduates which has increased from $11.5 \%$ in 2011 to $15.3 \%$ at the end of 2016 (ISTAT). The situation then becomes disturbing for young graduates, public and for government as well. The best option is thus, to move towards self-employed instead of looking for wage employment as a survival strategy.

The evidence from OECD nations showed that less than $10 \%$ of young population was involved in starting new ventures during early 2000s (Nolan, 2003). Twaalfhoven (2003)

(c) The Author(s). 2018 Open Access This article is distributed under the terms of the Creative Commons Attribution 4.0 International License (http://creativecommons.org/licenses/by/4.0/), which permits unrestricted use, distribution, and reproduction in any medium, provided you give appropriate credit to the original author(s) and the source, provide a link to the Creative Commons license, and indicate if changes were made. 
found that the proportions of the European students who are interested in becoming entrepreneurs within 3 years after their graduation are only $10 \%$. The situation is not very appreciable in Italy due to the noticeable dispersion of micro-firms and self-employment in total employment. For instance, the entrepreneurial activity was found less than $5 \%$ among adult population involved in starting and managing a new business which is significantly lower when compared to most advanced economies (Bosma and Leve, 2009). Furthermore, the startup rate of new businesses has constantly decreased, whereas the mortality rate of firms has been increased which generated a destructive and growing demographic imbalance (Arrighetti and Traù, 2006, 2012).

According to GEM (2014), among the innovation driven economies; Italy has the second lowest values for TEA (Total early-stage Entrepreneurial Activity) with the rate of $4.4 \%$. This remained stagnant during 2016 (GEM, 2016). The perception of entrepreneurial opportunities in Italy is also quite low, about the half of average of Innovation-Driven countries which can be due to the fear of failure (GEM, 2016). The data from previous studies revealed that the TEA always remained very limited in Italy in recent years, particularly after 2007. After the very low level (3.4\%) registered in 2013, it is back to $4.3 \%$ which is equal to the level seen in 2012.

The latest relevant studies conducted in Italy were by Ferrante et al. (2016) and Fini et al. (2016) who described the students' entrepreneurial engagement as well as their entrepreneurial intentions and showed a large share of intentional entrepreneurs in Italian universities. While in another relevant study, Arrighetti et al. (2013) estimated the sources of entrepreneurial intentions, differentiating between the propensity to start a new business and the perceived likelihood of becoming an entrepreneur. The latter study specifically discusses about the entrepreneurial mind-set of the students by analysing the influencing factors and provides a valuable contribution to the literature with the set of specific variables which is not currently available in the Italian context.

\section{Motivation of the study}

The aforementioned discussion provides the evidence of the insufficient entrepreneurial activities for the economic development in Italy and hence, seriously needs to be addressed. This would possibly be achieved through looking into the factors holding youth back moving toward self-employment. This is, in fact, the motivation of this study; to explore the facts behind the scene. Education plays an important and positive role in entrepreneurial performance. University students are young and highly educated potential entrepreneurs and the choice to focus on them justifies the reason of their role in future economic development in Italy (Ferrante, 2005; Van Der Sluis, Van Praag, and Vijverberg 2005; Van Der Sluis, Van Praag, and Vijverberg 2008). Moreover, new businesses created by university students and graduates are a powerful tool to bring new knowledge and strategies to the market which turns out spur productivity growth and job creation (Ferrante, Federici and Parisi, 2016). Thus, the university students signify the most capable segment of the future entrepreneurial supply and their response may have stimulating policy inferences.

\section{Objective of the study}

This sole objective of this study is to identify the motivational factors which can support university student in Italy to become entrepreneurs. 


\section{Research questions}

The major question of this research work revolves around which factors can motivate and hinder the entrepreneurial intentions among university students in Italy?

The following specific questions have also been addressed on the basis of the main question to explore the entrepreneurial intentions:

1- Do demographic factors such as age, gender, education level and grades, work and business experience, family background affect the entrepreneurial intentions among university students?

2- How do big five personality traits affect the entrepreneurial intentions?

3- Is there any relationship between entrepreneurial education and entrepreneurial intentions?

4- Does government support spurs entrepreneurial intentions?

5- Does finance availability promote the entrepreneurial intentions among university students?

\section{Literature review}

In recent years, entrepreneurship has played a major role towards job creation and contributed to economic growth and overall to national prosperity (OECD, 2012). In Europe, for the last many years promotion of entrepreneurship has become significantly important for the policy makers to lay down certain policies in order to boost up the entrepreneurship.

Entrepreneurial intentions stated by Thompson (2009) as "self-acknowledged conviction by a person that they intend to set up a new business venture and consciously plan to do so at some point in the future". Choo and Wong (2009) described entrepreneurial intentions as the exploration and assessment of information which is beneficial to achieve the objective of business creation. The focus of entrepreneurship is to have entrepreneurial intentions before starting the actual business because it determines the starting point of a new business creation. A personal commitment which has an important impact on shaping new ventures comes from entrepreneurial intentions (Choo and Wong, 2009). The literature on entrepreneurial intentions specifies the significance of self-employment intentions (Fridoline, 2009). Accordingly, identifying these intentions will allow the scholars to explore the dynamics of business venture creation process (Weerakoon and Gunatissa, 2014).

Kristiansen and Indarti (2004) identified the factors of entrepreneurial intentions in Norwegian and Indonesian students. They found high level of entrepreneurial intentions among Indonesian students which was due to economic challenges in Indonesia. While low level was found among Norwegian students, possibly due to high economic remunerations to employees. In addition, high level of entrepreneurial intentions existed in American students' compared to French students. The significant difference was due to already established entrepreneurial culture and the positive attitude towards new venture creation (Boissin et al., 2009).

In China, male students are more likely to become entrepreneurs than female students. Subsequently, American students' intention level was also found higher than Chinese students due to an entrenched culture of self-independence in the USA. 
However, the Chinese students with self-employment experience background had a stronger level of entrepreneurial intentions than American students (Plant and Ren, 2010).

Social environment factors through institutions such as legal rules and government support play a vital role in affecting individuals' entrepreneurship (Stephen, Urbano, and van Hemmen, 2009). Bridge, O'Neill and Martin (2009) added that entrepreneurial education plans, sponsoring enterprise advice, training centers, and giving financial support are the key elements, a government can provide to the new business start-ups to encourage and develop more businesses.

Generally, the availability of financial capital has been directly associated with entrepreneurship (Kim et al., 2013; Rodriguez et al., 2009). Potential entrepreneurs are needed to raise capital from other places as they hardly finance a new business completely by themselves (Steier and Greenwood, 2000). Empirical researchers showed that the lack of capital is considered as the major barrier for most entrepreneurs (Steel, 1994, Meier and Pilgrim, 1994) and that capital can come in the shape of gifts, support from family, friendly loans, or loans from financial institutions with interest.

The entrepreneurial education increases the entrepreneurship intentions and raises the knowledge and skills of individuals as well. Entrepreneurship intention can be influenced to address various subjective norms and resources which are barriers to create new ventures (Davey et al., 2011; Jones et al., 2011). It has been shown that positive relationship occurs between economics and business education and business creation. As a result, it can be seen by the intensive growth of business education in USA which has enhanced the levels of start-ups and new ventures (Drost, 2010). The entrepreneurial education has showed higher perceived entrepreneurial motivation than the students without enterprise courses (Solesvik, 2013). Subsequent studies also show that entrepreneurship education can possibly support graduates to become good entrepreneurs (Pickernell et al., 2011) as it increases the entreprneurial awareness among students which can encourage them to adopt entrepreneurship as a career and start new business ventures (Kirby, 2004).

The personality of students indirectly influences their intentions to start a new business through their attitudes (Lüthje and Franke, 2003). The personality traits can be categorised into two sets such as general and specific personality traits. The general personality traits include openness to experience, neuroticism, extraversion, agreeableness, conscientiousness, i.e. the big five; whereas, specific personality traits comprise locus of control, need for achievement, autonomy, risk-taking, innovativeness and self-efficacy. The present study focus on the general personality traits (the big five personality factors).

\section{Methods}

Regular and full-time (I and II bachelor and Master) students enrolled at University of Cassino and Southern Lazio (4000 appx.) were sent the questionnaires via email for a survey. However, due to incomplete/wrong email addresses in the student database, some students couldn't receive the questionnaires. The parameters of $5 \%$ margin of error, 99\% confidence level and $20 \%$ estimated response rate were fixed. Total 586 respondents were needed but only 510 students (both male and female) responded and 
produced 13\% response rate. Overall, after completion of survey, the actual margin of error was $5.33 \%$.

The research goals/questions of this study needed the exploration of certain relationships. The survey strategy was based on a self-prepared questionnaire designed in Italian language. Cronbach's Alpha test was used to analyse the reliability while $\mathrm{KMO}$ and Bartlett's test for the validity of the questionnaire. The questionnaire contained total 5 sections. The first section of the questionnaire contained demographic information. The second section was related to environmental support and involves two variables which are Finance availability and Government support. The third section described the entrepreneurial education. The fourth section was related to entrepreneurial intentions while the last section was devoted to the analysis of the personality traits.

A total of 18 independent variables (gender, age, degree, department, HS education, HS grades, job experience, business experience, family background (i.e. parent's education, parent's occupation), availability of capital, government support, entrepreneurial education, extraversion, conscientiousness, agreeableness, neuroticism, and openness to experience) were used to analyse the effect on the entrepreneurial intentions (dependent variable). Only continuous variables including entrepreneurial intentions were measured on the 5 point Likert scale. Multiple regression model was applied to analyse the date using IBM SPSS 22.

\section{Results}

Table 1 shows the frequency and percentages of all the categorical variables while the mean values and standard deviation are given for the continuous variables.

According to Tables 2, 10 variables which are Age, Gender (female), Previous grades, Mother occupation, Business experience, Entrepreneurial education, Extraversion, Agreeableness, Neuroticism, and Openness were showing significant values, which means that these are the only best predictors of the model. The last column of Table 2 shows the Collinearity Statistics where tolerance and VIF of all the variables are perfect and multicollinearity does not exist at all.

The detail of the analysis is as follows: University students with the age group of 2123 and 24-25 contribute less to the dependent variable (Entrepreneurial Intentions) as compared to the age group of 20 or less.

The slope of Female entrepreneurial intentions is significantly negative as compared to the slope of the male students which indicates that female students have less interest in entrepreneurship. Students with HS diploma grade from 60 to 70 showed a stronger intention towards entrepreneurship against the students with grades from 91 to 100 . The students whose mothers were entrepreneurs showed a positive influence on the entrepreneurial choice as compared to the students whose mothers are freelancers or employees. University students with any previous experience in starting or running a business were $20 \%$ more likely to become entrepreneurs as compared to the students without any business experience. Entrepreneurial education had a positive effect on students' entrepreneurial intentions as one unit increased in entrepreneurial education; intentions to become an entrepreneur increased by 0.09 units. In personality test, extraversion, agreeableness, and openness to experience showed a positive sign while neuroticism showed a negative sign. 
Table 1 Descriptive Statistics

\begin{tabular}{|c|c|c|}
\hline Variable & Frequency & $\%$ \\
\hline \multicolumn{3}{|l|}{ Gender } \\
\hline Female & 273 & 53.5 \\
\hline Male & 237 & 46.5 \\
\hline \multicolumn{3}{|l|}{ Age } \\
\hline 20 or less & 67 & 13.1 \\
\hline $21-23$ & 170 & 33.3 \\
\hline $24-26$ & 165 & 32.4 \\
\hline $27-29$ & 57 & 11.2 \\
\hline 30 or more & 51 & 10.0 \\
\hline \multicolumn{3}{|l|}{ Degree Program } \\
\hline Bachelor & 309 & 60.6 \\
\hline Master & 201 & 39.4 \\
\hline \multicolumn{3}{|l|}{ Department } \\
\hline Economics & 171 & 33.5 \\
\hline Law & 81 & 15.9 \\
\hline Engineering & 123 & 24.1 \\
\hline Humanities & 88 & 17.3 \\
\hline Literature and Philosophy & 47 & 9.2 \\
\hline \multicolumn{3}{|l|}{ Previous Education } \\
\hline Classical High School & 101 & 19.8 \\
\hline Scientific High School & 193 & 37.8 \\
\hline Artistic High School & 27 & 5.3 \\
\hline Education/Teaching School & 42 & 8.2 \\
\hline Arts Institute & 4 & .8 \\
\hline
\end{tabular}

Previous Education Grades

60

$61-70$

71-80

81-90

91-100

Father Education

No education

Elementary School

Middle School

Diploma

University

Mother Education

No education
Elementary School
Middle School
Diploma
University


Table 1 Descriptive Statistics (Continued)

\begin{tabular}{|c|c|c|}
\hline Variable & Frequency & $\%$ \\
\hline Freelancer & 73 & 14.3 \\
\hline Employee & 252 & 49.4 \\
\hline Entrepreneur & 84 & 16.5 \\
\hline Unemployed & 51 & 10.0 \\
\hline Retired & 50 & 9.8 \\
\hline \multicolumn{3}{|l|}{ Mother Occupation } \\
\hline Freelancer & 64 & 12.5 \\
\hline Employee & 192 & 37.6 \\
\hline Entrepreneur & 53 & 10.4 \\
\hline Unemployed & 163 & 32.0 \\
\hline Retired & 38 & 7.5 \\
\hline \multicolumn{3}{|l|}{ Job Experience } \\
\hline No & 232 & 45.5 \\
\hline Yes & 278 & 54.5 \\
\hline \multicolumn{3}{|l|}{ Business Experience } \\
\hline No & 468 & 91.8 \\
\hline Yes & 42 & 8.2 \\
\hline Variable & Mean & SD \\
\hline Capital Availability & 2.15 & 0.64 \\
\hline Government Support & 1.98 & 0.73 \\
\hline Entrepreneurial Education & 3.02 & 0.61 \\
\hline Entrepreneurial Intentions & 3.35 & 0.74 \\
\hline Extraversion & 3.54 & 0.84 \\
\hline Agreeableness & 3.92 & 0.78 \\
\hline Conscientiousness & 3.91 & 0.84 \\
\hline Neuroticism & 2.89 & 0.73 \\
\hline Openness & 3.95 & 0.67 \\
\hline
\end{tabular}

In Table 3, R square represents $27 \%$. In other terms, $27 \%$ of the variance in the dependent variable (entrepreneurial intention) is explained by the model, therefore, the regressors are sufficiently explain the response variable.

ANOVA results in Table 4 showed the fitness of the model. Based on the significance values (0.000), the null hypothesis was rejected and it was concluded that the overall model was fit and significant.

\section{Discussion}

Various categorical and continuous variables were analysed during the present study but only statistically significant variables are discussed.

To analyse the relation between age groups with students' entrepreneurial intentions, the age was inserted in the multiple regression model (Table 2). Although, only 2 age groups (21-23 and 24-25) were found with the statistically significant results in the comparison of the base age group (20 or less). It was concluded that the students with the age group of 20 or less are more inclined to become entrepreneurs as compared to the other groups. The younger individuals showed higher intention for entrepreneurial 
Table 2 Multiple regression model. Coefficients ${ }^{a}$

\begin{tabular}{|c|c|c|c|c|c|c|c|c|c|}
\hline \multirow[t]{2}{*}{ Model } & \multicolumn{2}{|c|}{$\begin{array}{l}\text { Unstandardized } \\
\text { Coefficients } \\
\end{array}$} & \multirow{2}{*}{$\begin{array}{l}\text { Standardized } \\
\text { Coefficients } \\
\text { Beta }\end{array}$} & \multirow[t]{2}{*}{$t$} & \multirow[t]{2}{*}{ Sig. } & \multicolumn{2}{|c|}{$\begin{array}{l}95.0 \% \text { Confidence } \\
\text { Interval for B }\end{array}$} & \multicolumn{2}{|l|}{$\begin{array}{l}\text { Collinearity } \\
\text { Statistics }\end{array}$} \\
\hline & $B$ & $\begin{array}{l}\text { Std. } \\
\text { Error }\end{array}$ & & & & $\begin{array}{l}\text { Lower } \\
\text { Bound }\end{array}$ & $\begin{array}{l}\text { Upper } \\
\text { Bound }\end{array}$ & Tolerance & VIF \\
\hline (Constant) & 2.539 & .408 & & 6.229 & .000 & 1.738 & 3.341 & & \\
\hline \multicolumn{10}{|l|}{ Age Group } \\
\hline Age_21-23 & -.232 & .099 & -.148 & -2.341 & .020 & -.427 & -.037 & .390 & 2.56 \\
\hline Age_24-26 & -.278 & .108 & -.176 & -2.571 & .010 & -.491 & -.066 & .332 & 3.01 \\
\hline Age_27-29 & -.260 & .136 & -.110 & -1.912 & .056 & -.526 & .007 & .465 & 2.15 \\
\hline 30 or more & -.162 & .146 & -.065 & -1.110 & .268 & -.448 & .125 & .446 & 2.24 \\
\hline \multicolumn{10}{|l|}{20 or less (base) } \\
\hline \multicolumn{10}{|l|}{ Gender } \\
\hline Female & -.234 & .066 & -.158 & -3.533 & .000 & -.365 & -.104 & .778 & 1.28 \\
\hline \multicolumn{10}{|l|}{ Male (base) } \\
\hline \multicolumn{10}{|l|}{ Degree } \\
\hline Master & -.053 & .078 & -.035 & -.681 & .496 & -.207 & .100 & .585 & 1.70 \\
\hline \multicolumn{10}{|l|}{ Bachelor (base) } \\
\hline \multicolumn{10}{|l|}{ Department } \\
\hline Law & .096 & .096 & .048 & 1.003 & .316 & -.093 & .285 & 689 & 1.45 \\
\hline Engineering & -.097 & .089 & -.056 & -1.095 & .274 & -.273 & .078 & .586 & 1.70 \\
\hline Humanities & -.061 & .093 & -.031 & -.651 & .515 & -.244 & .123 & .685 & 1.45 \\
\hline Philosophy & -.177 & .116 & -.069 & -1.522 & .129 & -.405 & .052 & .753 & 1.32 \\
\hline \multicolumn{10}{|c|}{ Economics (base) } \\
\hline \multicolumn{10}{|l|}{ Previous Education } \\
\hline $\begin{array}{l}\text { Classical High } \\
\text { School }\end{array}$ & .155 & .099 & .083 & 1.568 & .117 & -.039 & .348 & .552 & 1.81 \\
\hline $\begin{array}{l}\text { Scientific High } \\
\text { School }\end{array}$ & .036 & .082 & .024 & .437 & .663 & -.126 & .198 & .534 & 1.87 \\
\hline $\begin{array}{l}\text { Artistic High } \\
\text { School }\end{array}$ & .175 & .152 & .053 & 1.152 & .250 & -.124 & .475 & .733 & 1.36 \\
\hline $\begin{array}{l}\text { Educational } \\
\text { studies School }\end{array}$ & .061 & .124 & .023 & .496 & .620 & -.182 & .305 & .735 & 1.36 \\
\hline Arts institution & .041 & .346 & .005 & .118 & .906 & -.639 & .721 & .914 & 1.09 \\
\hline \multicolumn{10}{|l|}{ Others (base) } \\
\hline \multicolumn{10}{|l|}{ HS Grades } \\
\hline 60 & .357 & .166 & .093 & 2.156 & .032 & .032 & .683 & .823 & 1.21 \\
\hline $61-70$ & .233 & .102 & .113 & 2.293 & .022 & .033 & .433 & .641 & 1.56 \\
\hline $71-80$ & .140 & .091 & .078 & 1.536 & .125 & -.039 & .318 & .593 & 1.68 \\
\hline $81-90$ & .121 & .082 & .078 & 1.477 & .140 & -.040 & .282 & .561 & 1.78 \\
\hline \multicolumn{10}{|l|}{100 (base) } \\
\hline \multicolumn{10}{|l|}{ Father Occupation } \\
\hline Freelancer & .208 & .111 & .098 & 1.874 & .062 & -.010 & .425 & .565 & 1.77 \\
\hline Employee & -.112 & .088 & -.075 & -1.262 & .208 & -.285 & .062 & .436 & 2.29 \\
\hline Unemployed & .060 & .125 & .024 & .480 & .632 & -.186 & .306 & .604 & 1.65 \\
\hline Retired & .020 & .129 & .008 & .152 & .879 & -.234 & .273 & .578 & 1.73 \\
\hline
\end{tabular}

Mother Occupation 
Table 2 Multiple regression model. Coefficients ${ }^{\mathrm{a}}$ (Continued)

\begin{tabular}{|c|c|c|c|c|c|c|c|c|c|}
\hline \multirow[t]{2}{*}{ Model } & \multicolumn{2}{|c|}{$\begin{array}{l}\text { Unstandardized } \\
\text { Coefficients } \\
\end{array}$} & \multirow{2}{*}{$\begin{array}{l}\text { Standardized } \\
\text { Coefficients } \\
\text { Beta }\end{array}$} & \multirow[t]{2}{*}{$\mathrm{t}$} & \multirow[t]{2}{*}{ Sig. } & \multicolumn{2}{|c|}{$\begin{array}{l}95.0 \% \text { Confidence } \\
\text { Interval for B }\end{array}$} & \multicolumn{2}{|l|}{$\begin{array}{l}\text { Collinearity } \\
\text { Statistics }\end{array}$} \\
\hline & $\mathrm{B}$ & $\begin{array}{l}\text { Std. } \\
\text { Error }\end{array}$ & & & & $\begin{array}{l}\text { Lower } \\
\text { Bound }\end{array}$ & $\begin{array}{l}\text { Upper } \\
\text { Bound }\end{array}$ & Tolerance & VIF \\
\hline Freelancer & -.302 & .132 & -.135 & -2.300 & .022 & -.561 & -.044 & .449 & 2.22 \\
\hline Employee & -.331 & .107 & -.216 & -3.090 & .002 & -.542 & -.121 & .315 & 3.17 \\
\hline Unemployed & -.182 & .113 & -.115 & -1.619 & .106 & -.404 & .039 & .309 & 3.23 \\
\hline Retired & -.259 & .147 & -.092 & -1.761 & .079 & -.548 & .030 & .570 & 1.75 \\
\hline \multicolumn{10}{|l|}{$\begin{array}{l}\text { Entrepreneur } \\
\text { (base) }\end{array}$} \\
\hline \multicolumn{10}{|l|}{ Work Experience } \\
\hline Yes & .017 & .067 & .011 & .254 & .800 & -.114 & .148 & .768 & 1.30 \\
\hline \multicolumn{10}{|l|}{ No (base) } \\
\hline \multicolumn{10}{|l|}{ Business Experience } \\
\hline No & -.200 & .116 & -.074 & -1.714 & .087 & -.428 & .029 & .832 & 1.20 \\
\hline \multicolumn{10}{|l|}{ Yes (base) } \\
\hline Parents' Education & -.003 & .043 & -.003 & -.061 & .952 & -.086 & .081 & .787 & 1.27 \\
\hline Finance Availability & -.022 & .054 & -.019 & -.406 & .685 & -.127 & .084 & .713 & 1.40 \\
\hline $\begin{array}{l}\text { Government } \\
\text { Support }\end{array}$ & -.004 & .046 & -.004 & -.095 & .925 & -.095 & .086 & .745 & 1.34 \\
\hline $\begin{array}{l}\text { Entrepreneurial } \\
\text { Education }\end{array}$ & .082 & .029 & .118 & 2.824 & .005 & .025 & .140 & .883 & 1.13 \\
\hline \multicolumn{10}{|l|}{ Personality Trait } \\
\hline Extraversion & .123 & .042 & .138 & 2.904 & .004 & .040 & .206 & .681 & 1.46 \\
\hline Agreeableness & .114 & .045 & .119 & 2.501 & .013 & .024 & .203 & .686 & 1.45 \\
\hline
\end{tabular}

Conscientiousness-.015.040-.017-.365.715-.093.064.7531.32 Neuroticism-.085.043-.084-1.966.050

-.169 .000 .8551 .17 Openness.198.049.1804.050.000.102.295.7791.28 Dependent variable:

entrepreneurial intentions

behaviours than the older individuals, implying that individual's age is negatively related to entrepreneurial intention which is in consistent with the previous findings of Criaco (2012); Hatak et al. (2014).

Both international studies and the Danish Global Entrepreneurship Monitor (Schøtt, 2011; Amorós and Bosma, 2014;) found a consistent pattern of a larger share of males in the engagement of entrepreneurial activities compared to females (as measured by an intention to start a new business). The present study also explored that how gender might differ in entrepreneurial intentions. Table 2 shows that male (43.8\%) and female students $(56.2 \%)$ intend to start their career as employees. The share of intentional entrepreneurs among males was significantly higher $(25 \%)$ than among females. Interestingly, the share of male and female students who intend to become employees after 5 years of their graduation is lower for both male (14.3\%) and female (15.8\%) students and the share of female students was found slightly higher than the share of male students (Table 5).

Table 3 Model summary

\begin{tabular}{lllll}
\hline Model & $\mathrm{R}$ & R Square & Adjusted R Square & Std. error of the estimate \\
\hline 1 & $.521^{\mathrm{a}}$ & .271 & .213 & .65889
\end{tabular}


Table 4 ANOVA ${ }^{a}$

\begin{tabular}{lllllll}
\hline Model & & Sum of Squares & df & Mean Square & $F$ & Sig. \\
\hline 1 & Regression & 76.139 & 38 & 2.004 & 4.615 & .000 \\
& Residual & 204.477 & 471 & .434 & & \\
& Total & 280.616 & 509 & & & \\
\hline
\end{tabular}

a. Dependent Variable: Entrepreneurial Intentions

This investigation shows a positive relationship between university students' entrepreneurial intentions and their HS diploma grade. The students were asked to select their HS grades from given categories. In multiple regression model (Table 2), the first two categories (60 and 60-71) were statistically significant, indicating a negative relationship between grades and entrepreneurial intention among university students.

Family background were divided into two sections; parents' level of education and parents' occupation. It has been already pointed out by Ozaralli and Rivenburgh (2016) that families with entrepreneurial occupation provide youngsters with an opportunity to obtain certain business skills, confidence, experience, and vision, all of which contribute to the inclination to start a new business. In accordance, the results of present study showed that the students whose mothers were working as entrepreneurs had significantly more intentions to start a business, compared to the students whose mothers were involved in any other occupation. These results, thus, support the evidence of the previous studies (Shapero, 1984; Scott and Twomey, 1988; Katz, 1992) showing that the family background influences entrepreneurial intentions. Similarly, Peterman and Kennedy (2003) found that the intention to start a new business becomes more positive by prior exposure to entrepreneurship.

The statistically significant relationship between extraversion and students' entrepreneurial intentions was found and hence confirms the findings in the leadership literature which proposes that extraversion is positively related to leadership (Burch and Anderson, 2008). Furthermore, as individuals who are extravert, are usually more certain about their abilities, their intentions are louder than someone who is more introverted.

Openness to experience appears to be the personality dimensions that have the strongest effect on entrepreneurial intentions in this study because the individuals who score high in openness to experience are more likely to be intellectually curious, imaginative and creative, related to opportunity recognition (Ciavarella et al., 2004). The results showed that the openness personality traits have positive association with student's entrepreneurial intentions. The more the student was curious and imaginative, the more he/she is likely to start a business. The current findings support the previous studies i.e. Schumpeter (1911) who argued that exploring new ideas, being creative, and taking novel approaches were essential for starting a new venture as well as Caliendo et al., (2011) about the effect of openness on self-employment.

Previous studies suggest that entrepreneurs are expected to score lower on agreeableness (Singh and DeNoble 2003; Zhao and Seibert, 2006; Zhao, 2009). An agreeable individual is more likely to be manipulated and influenced by others (Liang et al., 2015). On the other hand, a high level of agreeableness was necessary to receive the required support, for instance, to start up a new venture. Entrepreneurs who create trusting, flexible and polite relationships with their customers should expect to reap the profits 
Table 5 Starting business after 5 years of the graduation * Gender Crosstabulation

\begin{tabular}{cllll}
\hline & & \multicolumn{2}{l}{ Gender } & Total \\
\cline { 3 - 4 } & & Female & Male & \\
\hline \multirow{3}{*}{ No } & Count & 230 & 203 & 433 \\
& $\%$ within Gender & $84.2 \%$ & $85.7 \%$ & $84.9 \%$ \\
& Count & 43 & 34 & 77 \\
& $\%$ within Gender & $15.8 \%$ & $14.3 \%$ & $15.1 \%$ \\
& Count & 273 & 237 & 510 \\
& \% within Gender & $100.0 \%$ & $100.0 \%$ & $100.0 \%$ \\
\hline
\end{tabular}

of repeat business (Ciavarella et al., 2004). Furthermore, high scores of agreeableness tend to reduce the rate of failure for entrepreneurs in vastly innovative businesses (Cantner, Silbereisen, and Wilfling, 2011). The results of this study are in line with Ciavarella et al., 2004, Cantner, Silbereisen, and Wilfling, 2011, as we found significant evidence of a positive relationship between agreeableness and students' entrepreneurial intentions.

Prior studies confirm that entrepreneurs tend to score low on Neuroticism which is the reversed version of emotional stability (Zhao and Seibert, 2006). This also comes back when observing the entrepreneurial personality positing that a high score on Emotional stability is anticipated for an entrepreneur (Schmitt-Rodermund, 2004). Emotional stability has shown a positive relationship with entrepreneurial performance (Zhao, Seibert, and Lumpkin 2010). Unexpectedly, our findings revealed that neuroticism, a negative emotionality such as feeling anxious, worried, touchy, and tense enhance entrepreneurial intentions. Uysal and Pohlmeier (2011) revealed that neuroticism had a negative association with the probability of finding a job. Thus, it seems that the lack of amiability and vulnerability motivate people with high neuroticism to build up their own business.

Entrepreneurial education is one of the most important and significant variables in this study. The findings reveal a strong relationship between entrepreneurial education and entrepreneurial intentions. Previous studies (e.g. Basu and Virick, 2008; Davey et al., 2011) support these findings. Likewise, Solesvik (2013) found that the students participated in entrepreneurial education had higher perceived entrepreneurial motivation than the students who did not study entrepreneurial courses. Therefore, it can be stated that a strong relationship and positive correlation exists between entrepreneurial education and intent towards entrepreneurship. However, only $10 \%$ of the students in this study have participated in any of the entrepreneurial course at least once at the time of this study. This implies that it is fundamental to have a good entrepreneurial education program to develop positive entrepreneurial intentions among students.

\section{Conclusion}

The objective of this study was to explore factors motivating the university students to embrace self-employment. To achieve this objective, the study explored the entrepreneurial intentions among the university students. The analysis confirms many previous findings in the literature on students' entrepreneurial intentions. For instance, the research has given further evidence of the importance of entrepreneurial education to make entrepreneurial mindset as well as supported the previous findings which stated 
that the male students were more interested towards entrepreneurship than the female students. This research also explored some interesting findings that the students with the younger age and low previous education grades were more inclined to become self-employed. This can make sense as the young blood is likely to take high risks which is considered as one of the essential entrepreneurial traits. Moreover, The creative individuals were often found with low grades or dropouts. Relating to the parents' occupation, students whose mothers were working as entrepreneurs showed positive response towards self-employment. Furthermore, the decision to start a new venture seems to be influenced by personality traits as extroversion, agreeableness and openness draw a positive while neuroticism has a negative impact on students' entrepreneurial intentions.

\section{Practical implications}

This study suggests that the universities should focus their attention on attracting students towards entrepreneurial education as students who attended entrepreneurial courses/trainings showed significantly higher entrepreneurial intentions. Therefore, universities are recommended to expand the number of entrepreneurship courses/ trainings as well as provide the opportunity to take entrepreneurial course/training to the students from all the faculties/departments of this university.

Furthermore, improving the image of entrepreneurship as a plausible career option could affect students' intentions towards entrepreneurship. The universities should promote entrepreneurship through entrepreneur and business role models to draw a positive image of entrepreneurship in the campus and to motivate students to pursue their projects. It is important to facilitate interaction between experienced entrepreneurs and the students.

\section{Limitations}

The present study was conducted on a limited and not probabilistic sample based on the students from the University of Cassino and Southern Lazio. Moreover, the limited sets of explanatory variables were assessed. Although, the questionnaire was sent to almost all the students of every department of the university, but 510 responses were received. Therefore, the results of this study are limited to its sample population. Factors such . as entrepreneurial intentions can change over time and could be influenced by other factors not covered in this study. The sample population and sets of variables can be extended in the future research

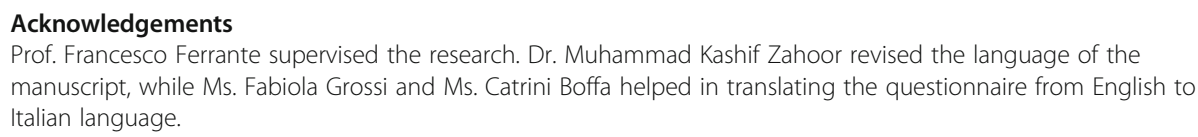

Availability of data and materials

The datasets generated and/or analysed during the current study are available wtih the name of [Data_Mentalità Imprenditoriale tra gli Studenti Universitari in Italia_Copy] repository, [https://drive.google.com/ open?id=1iMbTLnb2Wmd1sQDxvwj14L8hqzxB1148].

Authors' contributions

MI conducted the survey, research analysis, discussion and results while MS contributed in Literature review. Both authors read and approved the final manuscript. 


\section{Publisher's Note}

Springer Nature remains neutral with regard to jurisdictional claims in published maps and institutional affiliations.

Received: 10 November 2017 Accepted: 12 July 2018

Published online: 21 July 2018

\section{References}

Amorós, JE, and Bosma, N. (2014), "Global Entrepreneurship Monitor 2013 Global Report: Fifteen Years of Assessing Entrepreneurship across the Globe", Global Entrepreneurship Research Association (GERA) and Universidad del Desarrollo and Utrecht University.

Arrighetti and Trau. (2006). Struttura industriale e architetture organizzative: ipotesi sul 'ritorno' della gerarchia. Economia e Politica industriale, 1, 43-71.

Arrighetti and Trau. (2012). Far from the madding crowd: Sviluppo delle competenze e nuovi percorsi evolutivi delle imprese italiane. L'Industria, 1(Gennaio-Marzo), 7-60.

Arrighetti, A, Caricati, L, Landini, F, \& Monacelli, N. (2013). Explaining entrepreneurial orientation among university students: evidence from Italy. Working paper ep 04/2013.

Basu A. and Virick M. (2008), "Assessing entrepreneurial intentions amongst students: A comparative study", National Collegiate Inventors and Innovators Alliance Conference, Dallas, USA (pp. 79-86).

Boissin, JP., Branchet, B, Emin, S., and James, IH. (2009), "Students and Entrepreneurship: A comparative Study of France and USA", Journal of Small Business and Entrepreneurship, Vol 22 Issue 2, P 101-122,22P.

Bosma and Levie (2009). Global entrepreneurship monitor: 2009 global report. In Babson College / Universidad del Desarrollo / Reykjavik University.

Bridge, SO'Neill, K. and Martin, F. (2009), "Understanding Enterprise", Palgrave: London.

Burch, GSt. J., and Anderson, N. (2008), "Personality as a predictor of work-related behaviour and performance: Recent advances and directions for future research", In G. P. Hodgkinson and J. K. Ford (Eds.), International review of industrial and organizational psychology 261-305. Chichester, England: Wiley.

Caliendo, M, Künn, S, Schiidl, R. (2011). Fighting youth unemployment: The effects of active labour market policies. IZA DP No., 6222

Cantner, U, Silbereisen, RK, Wilfling, S. (2011). Which big-five personality traits drive entrepreneurial failure in highly innovative industries? DIME-DRUID Academy Winter Conference, 2011.

Choo and Wong. (2009). Entrepreneurial intention: Triggers and barriers to new venture creation in Singapore. Singapore Management Review., 28(2).

Ciavarella, MA, Bucholtz, AK, Riordan, CM, Gatewood, RD, Stokes, GS. (2004). The big five and venture success: Is there a linkage? Journal of Business Venturing, 19, 465-483.

Criaco, G. (2012). "The role of age as a determinant of entrepreneurial intention: Direct and indirect effects", Autonomous University of Barcelona. September, 2012.

Davey.T, Plewa.C, and Struwig, M (2011). Entrepreneurship perceptions and career intentions of international student. In Journal of education + training, (vol. 53, pp. 335-352). No: Pp.

Drost, EA. (2010). Entrepreneurial intentions of business students in Finland: Implications for education. Advances in Management, 3(7), 28-35.

Ferrante, F. (2005). Revealing Entrepreneurial Talent. Small Business Economics, vol., 2(September), 159-174.

Ferrante, F, Federici, D, Parisi, V. (2016). University students and entrepreneurship: Some insights from a populationbased survey. MPRA Paper No., 76980, Available at: https://mpra.ub.uni-muenchen.de/76980/ accessed 14 July 2017.

Fini, R, Meoli, A, Sobrero, M, Ghiselli, S and Ferrante, F. (2016) Student Entrepreneurship: Demographics, Competences and Obstacles. Technical Report - Almalaurea Consortium, February. Retrieved from: SSRN: https://ssrn.com/ abstract=2740541.

Fridoline, W (2009). Entrepreneurship proclivity today: An exploratory study on Students' entrepreneurship intention. Master Thesis in Business Administration University of Agder Faculty of Economics and Social Sciences.

GEM (2014), "Global Entrepreneurship Monitor Italia 2014".

GEM (2016), "Global Entrepreneurship Monitor Italia 2016".

Hatak, I, Harms, R, Fink, M. (2014). Age, job identification, and entrepreneurial intention. Journal of Managerial Psychology, 30(1), 38-53 ISSN 0268-3946.

Jones, MV, Coviello, N, Tang, YK. (2011). "International. Entrepreneurship research (1989-2009)", a domain ontology and thematic analysis. Journal of Business Venturing, 26(4), 632-659.

Katz, J. (1992), 'A psychological cognitive model of employment status choice'. Entrepreneurship Theory \& Practice, 17(1): 29-37.

Kim, PH, Longest, KC, Aldrich, HE. (2013). "Can you lend me a hand?", task-role alignment of social support for aspiring business owners. Work and Occupations forthcoming.

Kirby, DA. (2004). Entrepreneurship education: Can business schools meet the challenge? Education + Training, $46(8 / 9), 510-519$.

Kristiansen, S, \& Indarti, N. (March 2004). (2004), "entrepreneurship intentions among Indonesian and Norwegian students". Journal of Enterprising Culture, 12(1), 55-78.

Liang, Peng, Yao, and Liang, (2015), "Effect of personality differences in shaping entrepreneurial intention", International Journal of Business and Social Science Vol. 6, No. 4(1).

Lüthje, C, \& Franke, N. (2003). The 'making' of an entrepreneur: Testing a model of entrepreneurial intent among engineering students at MIT. $R$ and D Management, 33(2), 135-147.

Meier, R, \& Pilgrim, M. (1994). "Policy-induced constraints on small enterprise development in Asian countries", small enterprise. Development, 5(2), 32-38.

Nolan (2003). Entrepreneurship and local economic development. Paris: OECD.

OEDC (2012), Economic Policy Reforms, OEDC publishing at http://www.oecd.org/eco/monetary/ economicpolicyreformsgoingforgrowth2012.htm. 
Ozaralli, N, \& Rivenburgh, NK. (2016). Entrepreneurial intention: Antecedents to entrepreneurial behavior in the U.S.a. and Turkey. Journal of Global Entrepreneurship Research, 6, 3.

Peterman, N, \& Kennedy, J. (2003). Enterprise education: Influencing students' perceptions of entrepreneurship. Entrepreneurship Theory and Practice, 28(2), 129-144.

Pickernell, D, Packham, G, Jones, P, Miller, C, Thomas, B. (2011). Graduate entrepreneurs are different: They access more resources? International Journal of Entrepreneurial Behaviour and Research, 17(2), 183-202.

Plant, R. and Ren, J. (2010), "Comparative study of motivation and entrepreneurial intentionality: Chinese and American perspectives", Journal of development entrepreneurship, Vol. 15 issue 2,P 187-204.18 P DOI:10,1142

Rodriguez, P, Tuggle, CS, Hackett, SM. (2009). An exploratory study of how potential 'family and household capital' impacts new venture start-up rates. Family Business Review, 22(3), 259-272.

Schmitt-Rodermund, E. (2004). Pathways to successful entrepreneurship: Parenting, personality, early entrepreneurial competence and interests. Journal of Vocational Behavior, 498-518.

Schøtt, T (2011). Entrepreneurial work by employees in enterprises - studied via global entrepreneurship monitor in Denmark 2011. University of Southern Denmark.

Schumpeter Joseph (1911), "Theorie der wirtschaftlichen Entwicklung".

Scott, M, \& Twomey, D. (1988). The long-term supply of entrepreneurs: student's career aspirations in relation to entrepreneurship. Journal of Small Business Management, 26(4), 5-13.

Shapero, A (1984). The entrepreneurial event. In CA Kent (Ed.), The environment for entrepreneurship. Lexington: Lexington Books.

Singh, G, \& DeNoble, AF. (2003). Views on self- employment and personality: An exploratory study. Journal of Developmental Entrepreneurship, 88(3), 265-00.

Solesvik, MZ. (2013). Entrepreneurial motivations and intentions: Investigating the role of education major. Education and Training, 55(3), 253-271.

Steel, WF. (1994). Changing the institutional and policy environment for small Enterprise development in Africa. Small Enterprise Development, 5(2), 4-9.

Steier, L, \& Greenwood, R. (2000). Entrepreneurship and the evolution of Angel Financial networks. Organization Studies, 21(1), 163-192.

Stephen, FH, Urbano, D, Van Hemmen, S. (2009). The responsiveness of entrepreneurs to working time regulations. Small Business Economics, 32(3), 259-276.

Thompson, ER. (2009). Individual entrepreneurial intent: Construct clarification and development of an internationally reliable metric. Entrepreneurship: Theory and Practice, 33(3), 669-694.

Twaalfhoven, B.W.M. (2003), "Red paper on entrepreneurship", paper presented at the 4th European symposium, November 18-19, Louvain-la-Neuve, Belgium.

Uysal, S, \& Pohlmeier, W. (2011). Unemployment duration and personality. Journal of Economic Psychology, 32(6), $980-992$.

Van Der Sluis, Van Praag, \& Vijverberg (2005). Entrepreneurial selection and performance. A meta-analysis of the impact of education in Industrialized Countries, World Bank Economic Review 19(2), 225-261.

Van Der Sluis, Van Praag, and Vijverberg (2008), "Education and entrepreneurship selection and performance: A review of the empirical literature", Journal of Economic Surveys 22(5), 795-841.

Weerakoon, WMPGC, \& Gunatissa, HHAJ. (2014). Antecedents of entrepreneurial intention. International Journal of Scientific and Research Publications, 4(11).

Zhao, H, \& Seibert, SE. (2006). The big five personality dimensions and entrepreneurial status: A meta-analytical review. Journal of Applied Psychology, $91(2), 259-271$.

Zhao, H, Seibert, SE, Lumpkin, GT. (2010). The relationship of personality to entrepreneurial intentions and performance: A meta-analytic review. Journal of Management, 36(2), 381-404

Zhao, Y. (2009), "Catching up or leading the way: America education in the age of globalization", p-82 Available at: http://bit.ly/2h5YdvY (accessed 20 June 2017)

\section{Submit your manuscript to a SpringerOpen ${ }^{\circ}$ journal and benefit from:}

- Convenient online submission

- Rigorous peer review

- Open access: articles freely available online

- High visibility within the field

- Retaining the copyright to your article

Submit your next manuscript at $\boldsymbol{\sim}$ springeropen.com 